\title{
NEWS IN THE IT OUTSOURCING AND TRENDS \\ IN ITS DEVELOPMENT
}

\author{
Jolanta Stoniec \\ Lublin University of Technology, \\ Faculty of Management, Department of Enterprise Organization, Lublin, \\ Poland \\ e-mail: j.sloniec@pollub.pl
}

\begin{abstract}
The aim of the article is to show new trends in the development of IT outsourcing (ITO) and indicate possible directions of the development of the branch. The methods used in the study are: desk research, analysis and synthesis, case study novelties in the ITO branch. Outsourcing as a concept of business management focused on slimming organization appeared at the end of the twentieth century and is currently undergoing intensive development. The value of the outsourcing market, especially IT outsourcing is increasing. The number of companies using this form of service, as well as the number of companies - service providers - are growing rapidly. Both theoreticians and practitioners are seeking management methods and techniques for improving this form of service. What adds to the news of ITO are: the use of cloud computing, automation and robotics, the use of artificial intelligence, crowdsourcing, reverse outsourcing, new forms of employment, new professions and next countries - the ITO service provider. Directions of development of the branch are related to social, organizational and technology areas, and focus on these news of ITO. In the social area one should note a growing importance of Asian countries and Central and Eastern Europe countries, including Poland as a country with great potential to provide IT outsourcing.
\end{abstract}

Keywords: IT outsourcing, history of outsourcing, future of IT outsourcing

Paper type: General review

\section{Introduction}

Computers have dominated today's world, and the digital revolution is changing the way of operation by modern enterprises. The growing potential of the IT industry encourages companies to change business processes and reach for new forms of IT services. They are often provided in a form of outsourcing. Forms of IT outsourcing also undergo transformations, market-driven development of new forms of service delivery. The fundamental reason for changes are: technological progress, development of network services and the widespread 
Jolanta Słoniec use of cloud computing to store data and information. Knowledge as the most valuable corporate asset must be readily available, and the information and data should be catalogued, segregated, stored, protected and shared. Access to current information often determines competitive advantage of the company, its position and even its existence in the market. The need for properly qualified employees in the field of IT human resources as the most important element of business process encourages companies to use the ITO in a form of a body or leasing team. The value of the IT market is constantly growing, as well as the ITO. Almost all companies, even the most resistant in relation to IT technology, tend to use these technologies to a greater or lesser extent, often without having adequate knowledge on using the services of specialists in a form of IT outsourcing.

\section{Short history of outsourcing development in the world and in Poland}

The idea of outsourcing is not a new phenomenon and is at least a few hundred years old, although the name was established in the twentieth century. The kings of European countries commissioned religious orders to organise education in a form of schools, institutes and colleges (Nogalski, 2010), for instance, the Jesuit colleges. Napoleon used outsourcing of commissioning private providers to deliver ammunition (Grudzewski and Hejduk, 2014). As K. Obłój indicated (by Trocki, 2001), all companies have suppliers and subcontractors, so they use outsourcing. Based on this statement, you will find that outsourcing has spread on a large scale during the development of craft production in the eighteenth century. During the industrial revolution the nineteenth and early twentieth century American industrialist, Henry Ford, formulated the basic principle of outsourcing, which says that if you cannot perform a task well, it would be better if someone else will do it (Niedźwiedzka, 2002).

The term outsourcing appears in the science in the 1990s (Trocki, 2001). Under its current name the concept of outsourcing came to practice of management in the $80 \mathrm{~s}$. In the $60 \mathrm{~s}$ and $70 \mathrm{~s}$ it was used to name the shared work of workers (Grover et al., 1996). In the same period, when the existing and new management concepts developed, the concept of outsourcing was applied to the implementation of the IT function.

The precursor of use of outsourcing in the IT industry was R. Perot, whose company offered paid tasks associated with IT to Frito-Lay concern - the company managed IT equipment. In the 80s General Motors termed external supply of auto parts to their factories as outsourcing. The evolution of outsourcing (by Szymanski, 1999; Trocki, 2001) took place in the following progressive stages (Figure 1):

- Outsourcing as a method to reduce costs,

- Outsourcing as a way to reduce the risk of technological changes,

- Outsourcing as a concept to focus on key activities,

- Outsourcing as a strategic choice of functioning. 


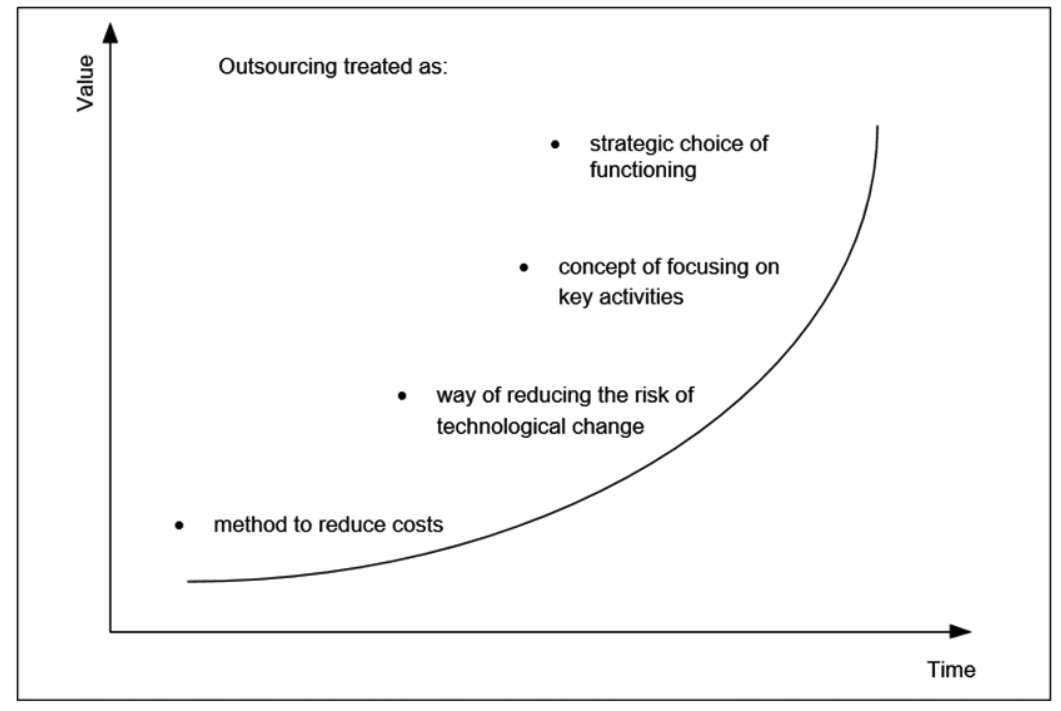

NEWS IN

THE IT

OUTSOURCING

Jolanta Słoniec

Figure 1. Evolution of outsourcing

Source: (by Szymański, 1999;

Trocki, 2001).

In the following years outsourcing has expanded into other areas of business activity, covering almost all areas, except for the core business.

It should be noted that the United States of America is considered to be the motherland of modern outsourcing.

The name outsourcing comes from English words outside resource using that mean the use of resources from outside the organization. There are many definitions of outsourcing, of which three are mentioned:

- "transferring business processes to service provider" (Williams et al., 2011),

- "project of separation some associated functions from the organizational structure of the parent company and transfer them for the realization to other economic entities" (Trocki, 2001),

- "set of long-term restructuring activities, involving the separation of some business activities and functions from the company, which can take over external partners" (Nogalski and Wójcik-Karpacz, 2003).

In the cited definitions it is indicated that the basic feature of outsourcing is the secretion from the organization certain functions and activities and transfer them to the execution to external entities.

IT outsourcing is also defined as a separate phenomenon, defined as:

- "the decision taken by the organization to accept the contract or the sale of assets of information and / or working activities to the supplier, who will provide and manage the assets and services in turn for a limited time for remuneration" (Kern and Willcocks, 2000), 
Jolanta Słoniec
- “(...) IT outsourcing (...) will be understood as a transfer to an external provider to manage and implement the functions and processes related to the use of information technology, along with their associated assets and personal assets" (Kluk, 2014).

Definitions of ITO focus on certain functions, which are functions related to the use of information technology.

Development of IT outsourcing in Poland is ahead of the development of the industry in the world. The precursor of IT outsourcing in Poland is a stateowned enterprise ZETO (Plant of Electronic Computing Technology) created by the decree of the President of the Polish Committee of Science and Technology in 1964 with offices in several large Polish cities. The purpose of the company was the service of data collection and its processing by state institutions, organizations and enterprises. In subsequent years, ZETO was the subject of many transformations, branches in some cities were closed, but today there are some, which transformed and provide services in the field of IT outsourcing. ZETO case proves that Poland was very early in the group of countries developing IT techniques, including IT outsourcing services.

It should be noted, however, that the widespread development of IT outsourcing took place in Poland in the 1990s.

The phenomenon of globalization by outsourcing production processes to the regions and countries where the work is less payed contributed to the development of the ITO (Heeks et al., 2001). The second reason was a general acceptance of the use of the Internet as a medium to communicate, which manifests itself, for example, in application outsourcing (Marchand and Jacobsen, 2001).

In recent years, there was a significant increase in the ITO market, including the size and scope of IT outsourcing services (McLellan et al., 1995; Palvia, 1995; Caldwell, 1996; Lacity and Willcocks, 1998). It seems that this growth will continue, as confirmed by the results of previous ITO market analysis.

\section{Present of OIT in Poland}

Outsourcing is used in many areas of business. The main areas of its application in Poland include: logistics, general management, administration, IT, telecommunications, finance, production management, marketing and HR (Kłos, 2009).

On the basis of his research, (Radło, 2013) Radło draws attention to the positive impact of internationalization associated with the use and offering OIT, which affects the development of the economy as a whole, including the development of the Polish economy.

The branch of IT outsourcing is one of the industries that are developing very fast today. The research conducted in 2015 by Orange indicates that " $63 \%$ of large companies and corporations say that IT outsourcing allows them to build 
competitive advantage, 55\% see an increase in its importance in recent years, and almost half (45\%) say that the use of IT outsourcing is not without relevance to business efficiency" (Baranowska-Skimina, 2015).

Projections for the future of IT outsourcing made on the basis of the research of KPMG in years 2014/15 show that in the next 2-3 years, the main reasons for planning to purchase outsourcing will be: cost reduction $-26 \%$, quality improving $-21 \%$, access to skills $-19 \%$, financial flexibility $-11 \%$ and access to the latest technology $-11 \%$ (Wroński et al., 2015).

The potential of Poland expands as a provider of outsourcing business services and IT. Poland is sometimes called the India of Europe. Krakow was ninth in the report Top 100 Outsourcing Destinations 2015 (Warsaw - 30 ${ }^{\text {th }}$ place, Wroclaw $62^{\text {nd }}$ ) (Albin, 2016).

The following data may indicate the level of development of IT outsourcing in 2016 in Poland (Podhorecka, 2016):

- An employment in centres of services amounts to 221 thousand people, including 177 thousand in foreign centres and 35 thousand in Polish centres;

- The number of centres of services in Poland is 936, including 676 foreign centres;

- The growth of employment in foreign centres in the last year was $25 \%$ higher than in previous years;

- The projected number of employees in centres of services in 2020 will amount to 300 thousand people.

\section{News in the OIT branch}

Referring to the directions of development of ITO it should be noted that the value of IT outsourcing market is clearly growing, and this growth takes place not only because of the use of existing solutions, but also as a result of the use of new, more efficient technologies and methods. Using division planes of outsourcing development proposed by Kopczyński (Kopczyński, 2010) on: social, organizational (soft aspects of management) and technological (hard aspects) you can make the following classification of novelties in the development of ITO:

- Social area:

- New forms of employment and new professions of employees in ITO,

- New countries - ITO service providers.

- Organizational area:

- Reverse outsourcing,

- Crowdsourcing.

- Technological area:

- The use of cloud computing, 
- The development of technology (use of spreadsheets, automation and robotics of processes, the use of artificial intelligence).

The first trend is robotics and automation (Podhorecka, 2016; Overby, 2015; Rhiza, 2016; Balentine, 2016) solutions based on artificial intelligence and design thinking. Through the trend approximation of business processes and technologies occur. In the digital economy based on 3.0 services, it is impossible to make business decisions based on average values, as it was before. Currently, the business seeks to maximize the use of digital technology in order to make decisions based on real and current data.

Repetitive tasks are entrusted now to the machines and robots.

Repetitive tasks can be divided into three groups of fairly simple to very complex: 1 - spreadsheet-based, 2 - automation through robotics, when you configure the software to your needs, saving activities and then the system automates them, 3 - artificial intelligence and processes of learning up, which include speech and handwriting recognition and automated decision-making systems. Although the last of these systems are not yet perfect, it is sought to create, for example, agents in a call centres or virtual assistants. This eliminates the need of language knowledge, particularly rare, which reduces costs. However, the overriding goal of automation and robotics is the elimination of repetitive, boring tasks, reluctantly performed by employees.

This trend can also include new solutions used in call centres (Karasowski and Skalski, 2016). A consultant who contacts with the customer has the basic knowledge about him or her and calls the customer at a convenient time (customer database). No customer call to the company remains unanswered, even when the phone line is busy. The customer then receives information about the number of people waiting for a call and an incentive to leave their contact details and information, when the company can call them back.

These actions allow you to leave a good impression of the company as a potential partner and build a serious business relationship with the customer. The systems used in call centres are delivered in a form of an outsourced application, and customers' databases are stored on remote servers. It can also be called centres in the cloud, where the services are easily configured in online dashboard (automated announcements system, forwarding to mobile numbers or voicemail, queuing). Call centre in the cloud is a solution for both single businesses as well as for large companies and the system is always configured according to individual customer's needs.

The second direction in the development of IT outsourcing, is crowdsourcing, that means the use of "crowd effect" (Podhorecka, 2016). This applies to orders that require a lot of employees for only a short time, such as support for large cultural or sports events. In this case a suitable solution can be a crowdsourcing platform, which contains the data of hundreds or thousands of employees. 
Employees are also increasingly looking for flexible work, that is only on certain days and hours. In countries where there are crowdsourcing platforms, the value of an investment in such services is increasing many times each year.

The third trend is the development of digital technologies, mainly based on cloud computing. Rarely do modern companies have physical servers and corporate data stores in the cloud computing. Currently, many workers in companies work on remote computers. Services in collecting, storing, securing, sharing and managing data are provided by specialized companies. Big data sets are administered centrally by specialized companies. It should be payed attention to problems of data and processes security, but these elements are much better protected by outsourcing service providers than inside the company. Often the protection of data and processes also takes place in a form of outsourcing. Cloud computing benefits from the latest hardware and software technologies.

The fourth trend relates to the emergence of new professions, functions and forms of employment (Podhorecka, 2016). New professions include professions related to safety trials and data storage, such as security engineers and experts, also in cyberspace. Digital technologies and work with large databases requires appropriate staff - big data analysts, architects, managers. When it comes to new forms of employment it is to hire individuals or project groups (body and group leasing), hire the employee on request strictly temporary or vice versa working employee in strictly specified time. One should also mention new ways of managing people (Kopczyński, 2010), based on conduction, rather than directing people to take advantage of specific skills and knowledge of employees to achieve productivity growth.

Another, the fifth trend is the new concept called Built-Operate-Transfer (BOT) (Podhorecka, 2016). It involves another entity that undertakes business activity for the company of the host of the venue. This concept is called too reverse outsourcing. The concept of reverse outsourcing is used especially in companies where there is low acceptance of this form of services among employees, so that over time the employees get used to the fact that someone else can perform certain functions and operations of the company better than themselves. However, it happens sometimes that the company does not want to worry about the services centre and commissions continuing the execution of previously outsourced functions.

The sixth trend is associated with countries where IT outsourcing services providers have their headquarters. Currently, a significant place among the countries services providers reside in Asian countries, especially India, Korea, China, as well as Central and Eastern Europe countries, including Russia, Lithuania, Ukraine, Czechia, Slovakia and Poland (Cushman and Wakefield, 2015; Bhushan Dhiraj, 2014; Wallingford, 2016). They have become an attractive location and a seat of many international companies operating in the IT services 
NEWS IN

THE IT

OUTSOURCING

Jolanta Słoniec

Figure 2. Diagram of novelties in the development of IT outsourcing

Source: own elaboration. industry. In Poland, a lot of new flexing developing Polish companies providing IT services were created. The cause of the development of the IT sector in Poland are still somewhat lower than labour costs in Western countries, with the same quality of services and the same level of knowledge and skills of employees (Waszczuk, 2016). Poland is a country with a huge number of highly educated professionals in the IT industry. Figure 2 shows a diagram of novelties in the development of IT outsourcing.

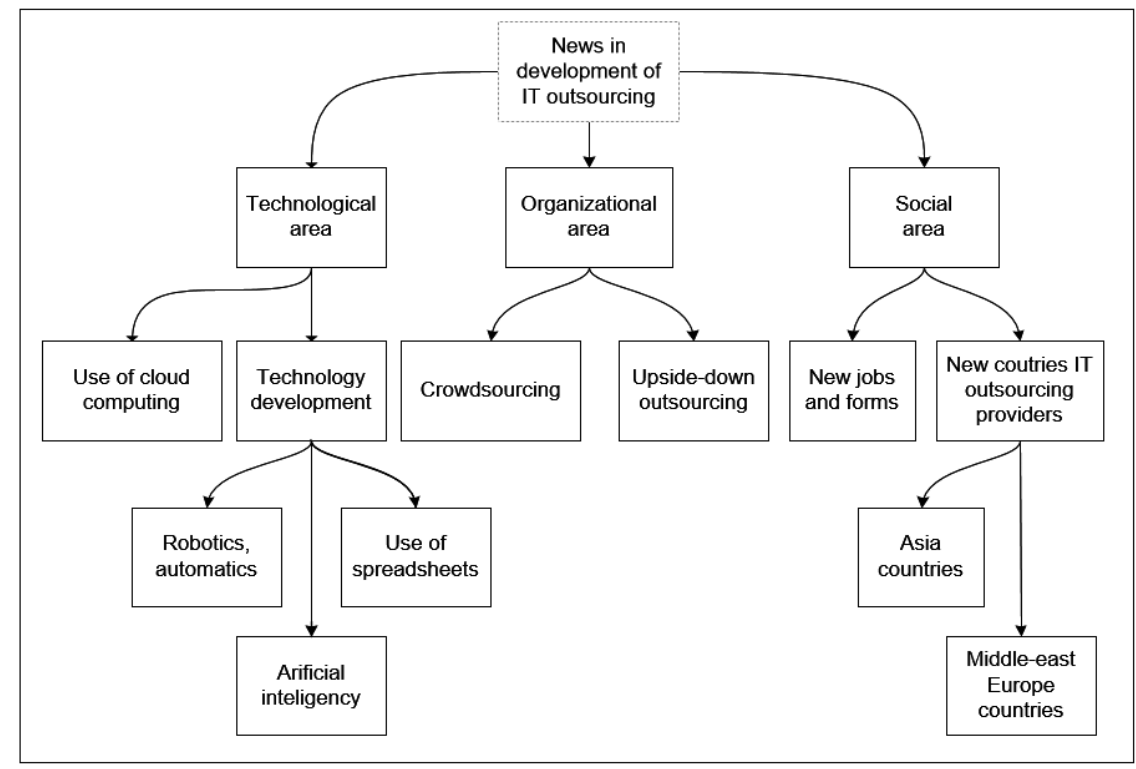

Some experts call this changes in the IT industry another technological revolution. It will be primarily based on new digital technologies, but also on new jobs and functions necessary to perform new tasks. This will include: experts coordinating the content of websites and mobile applications, engineers manage changes, experts remotely supporting data centres, engineers for safety. The technological revolution is already present in Poland and according to the IT industry analysts' expectations its presence in Poland will increase.

About outsourcing development here written Overby S. and Rhiza C. listing the following trends: (Overby, 2015; Rhiza, 2016): 1. Security, 2. Back from offshoring to the implementation their own resources to IT, 3. Cloud services development, 4. Multi-sourcing, 5. Integration challenges surge, 6. Expansion of the service providers universe, 7. Introduce multi-speed IT outsourcing, 8. Accommodative approach to meeting needs of companies, 9. Automation of works, processes and procedures, 10. Agile Sourcing. 


\subsection{Core services company}

Due to their educated staff and developed business culture, Western companies launch SSC - shared services centres in Poland. Therefore, both the SSC and local outsourcing companies stimulate the development of IT outsourcing in the field of IT professionals. CEO of CORE Services states that (Wędzicha, 2016) in the industry in which the company operates the employee has a dominated position.

CORE Services Company is engaged in IT outsourcing. It has been operating since 2010. It has an extensive database of professionals from the IT industry in Poland. The scope of business includes software development projects, business analysis, implementation and integration of applications, IT infrastructure management. The company offers the following models of collaboration: outsourcing specialists, team leasing, team training, nearshore.

If a company has to do a project and misses employees in the team, the only way to fill in the gaps is to use the offer of one or more outsourcers. In recent years, some companies decide to expand IT departments and independent implement of IT projects. So the project is open and can be modified according to customer's needs without having to ask the authors of the solutions for permission to modify the system. This also allows for independence from external suppliers. However, the implementation of projects requires a specialized team of employees, and in enterprises they are often missing. Hiring a full-time employee is costly and inconvenient, especially when the project is completed. Therefore, the best solution is to outsource a person or a group of employees from specialized organizations.

Nowadays, outsourcing companies in the IT industry are a long-term workplace for professionals, providing them with access to training, interesting projects realised for different clients and other benefits of a full-paid employment.

In the future, the problem may be a saturation of the specialists market. High demand for specialists stimulated by SSC will lead to an increase in salaries and optimal use of resources. This gives a chance to outsourcing companies which offer IT professionals.

\subsection{Progress group}

Until a few years ago, the process of recruitment took place face to face with the candidate for an employee, both with relation to companies and potential employees. Currently, this process is done very often via the Internet. Vice president of Progress Group (Maciołek, 2016) states that in spite of robotics and automation of production and business processes constantly there is a need for qualified workers. So, employers employ workers from the East of Europe: Ukraine, Belarus, but also from Asia. As a result of the technological 
Jolanta Słoniec revolution many professions disappeared, but also new professions associated with IT industry appeared. Firms are trying to obtain, analyse and synthesize information needed to make business decisions. It is rising the importance of such professions as big data scientist, big data analyst, big data architect. Therefore, the company Progress Group hires - outsource experts with specific professional qualifications to perform specific, time-limited tasks. Following the example of Western companies which used such forms of employment for a few years, the company becomes the architect of business processes to customers, which allows to maintain a constant contact with customers for a long time.

\subsection{Impel S.A. Company}

Facility Management (FM) includes services related to business processes (BPO) and refers to IT services, accounting services, tax consulting, archiving and digitizing documents. CEO of Impel SA (Dzik, 2016) argues that changes in the labour market and new technologies have impact on FM. Outsourcers are well aware of the need for automation and robotics of processes, integration of services and the introduction of service packages. The customer now expects to participate in the design, improve and innovate in the ordered service. Employers have to accept the fact that in Poland people do not want to work for low wages, not only in specialized services, but also in the simplest professions. Therefore, new technologies are gaining in importance, allowing digitization, automation and implementation of common innovation. In the service packages customers are looking for synergies at the package level, that is, the additional benefits of the package, and not only a lower price.

\subsection{Mazars Company}

The ability to provide business information at an attractive price is one of the determinants of the development of the outsourcing industry. As partners of Mazars the company says (Kiviatkowski and Nowecka, 2016) says the first trend of outsourcing development is to invest in modern technological tools electronic circulation of documents in companies has become a standard. The goal is to deliver reliable and correct information quickly.

The second trend is the issue of data security, because often the processes take place in the cloud. So, outsourcers use professional security of processed information.

The third trend is the outsourcing into outsourcing, that is, the use by outsourcing companies the services subcontractors, sometimes even both are working in the same area, in order to expand the range of services and reduce costs. This form are using shared service centres (SSC) and big international organizations. SSC can offer a very high level of services at an attractive price, because the companies automated processes for repetitive tasks. To perform the 
tasks that cannot be automated, for example, for drawing up financial statements, SSC are looking for a suitable partner.

The fourth trend is to change the relation of business to service providers and increase the trust to the service providers. Providers usually do projects that are not in a main area of enterprises activity, but to do projects providers need openness and sincerity. Outsourcing relationships always depends on people and on the company's corporate culture.

\subsection{Lviv IT Cluster}

Lviv Cluster of IT (Vesolovskij and Doktór, 2015) is the oldest (it has been operating for 15 years) and the largest in Ukraine. Annual value of the market for this cluster is about 290-300 million dollars and it represents approximately $30 \%$ of the annual value of this market in Ukraine. The export of ICT services (information and communications technologies) in Ukraine is 5 billion dollars and, according to forecasts, it may exceed 15 billion dollars in 2020. In Ukraine, in the ITO it employed 75.000 people, from which $20 \%$ work in Lviv.

IT is now the third largest sector of the economy of Ukraine, the ITO is the second economic sector in Lviv. The turnover of the IT industry is higher than the city budget. Lviv cluster of IT opens its representative offices in the countries of Central and Eastern Europe, including Poland. The firms of ITO intensify their cooperation with Polish counterparts. The aim of the cooperation is to create a "win-win" situation - both sides (one or more) are gaining from the cooperation, they are all winners. The aim of the Ukrainian companies are not taking over contracts from Polish companies, and the intention of the Polish companies is not only seeking employees in Ukraine (Such cooperation would have no future), but to build a specific IT and ITO empire together in order to gain a lot more.

The news in the ITO in the cluster can be divided into three groups, relating to: the business (the way of doing business, business models, relationships, forms of activities), the products (applications, services, groups of applications and services, relationships) and the technologies (remote, mobile, in cloud, hardware).

\section{Trends of outsourcing and OIT development}

Outsourcing as a developing concept of enterprise management evolves according to the conditions of modern management.

Considering trends of outsourcing development, Kopczyński (2010) focuses especially on the soft aspects - the social and organizational areas. He points out the following trends: eliminating employees' resistance to outsourcing, new methods

of managing people based on influencing, communication and motivation, adapting organizational cultures of outsourcing partners.

Based on the news in the branch of ITO divided into three areas you can outline possible directions of its development. In the technology area you should expect 
Jolanta Słoniec further expansion of the use of cloud computing, in particular the development of new technologies for every aspect of the use of cloud computing: the collection, transfer, separation, securing, sharing and management of data, new applications and network and mobile technologies.

In the area of technology, it is likely to become widespread, further automation and robotics of functions and processes, as well as the use of artificial intelligence, expert and learning systems.

In the organizational area, one can observe further exploration of methods associated with individualization of employment, work on order or contract for a specific project, at a specified time. The expansion of the area and scope of remote work, performed by the employees from their houses also seems likely in ITO. This significantly reduces the costs of running offices.

In the social area the development of existing and creation of new professions related to new technologies used in the ITO and technologies related to the use of cloud computing should be expected.

Auksztol draws attention to the development of the concept of outsourcing (Auksztol, 2008), which will be followed based on the theories of institutional economics, supplemented by the theory transaction costs. The development concerns the object of the contract as the basis of relations resulting from the accepted rights and obligations, and the contractual institutions, understood as a set of provisions contained in the contract.

The future of IT outsourcing seems optimistic, and the development of the market and increase of its value will make it possible to finance works on improving the substance aspects and the quality of services provided by the ITO services providers.

\section{Conclusions}

The article presents the news in the ITO and possible directions of development of the industry. The news in the ITO were classified in three areas: social, organizational and technological. In the area of technology one can distinguish the use of cloud computing, the automation with the use of spreadsheets, robotics of processes and repetitive tasks, tedious and reluctantly performed by employees, and the increasing use of artificial intelligence and learning systems (agents and virtual assistants).

In the organizational area you can note searching for new forms of organization of business processes from a lesser to greater extent, as well as the optimization of existing processes. The novelties here are, for example, crowdsourcing, which is called the effect of the crowd, when a large group of workers is needed for a short time to organize a project and reverse outsourcing, when a foreign company settles their business in our venue to provide a service for us, consisting of their employees. The company provides services for us in a strictly defined area, such as IT. 
After several years of such successful cooperation, the established company is taken over by the customer or is not acquired and then it can provide services as an outsourcer. In the social area, the innovation is creating new professions in IT industry or in management, associated with the use of new technologies and with changes in the organization of business processes. Also new are countries ITO services providers and it is not only opening the agencies of Western companies in Central and Eastern Europe or in Asia, but also the development in the countries of Central and Eastern Europe and Asia, new, thriving businesses providing services in the IT industry. It will also increase employment in the industry.

As expected by theoreticians and practitioners of IT and management (Kopczyński, 2010; Podhorecka, 2016; Vesolovskiy and Doktór, 2015), the progress of the industry will follow in this direction. Development in each of the separate areas as well as development between these areas should be expected. And so, new professions and forms of employment are going to develop because of technological and organizational advances.

On the other hand, technological progress (new applications) occurs, because such are the demands of the market, due to the development of new forms of employment, the development of new forms of doing business. Organizational changes occur as a result of the development of technology and changes in the social area. It can therefore be argued that the areas and directions of ITO development are coupled with each other and mutually imply its development. Graphically, the relationship between new trends in ITO development could be presented in a graph (Figure 3).

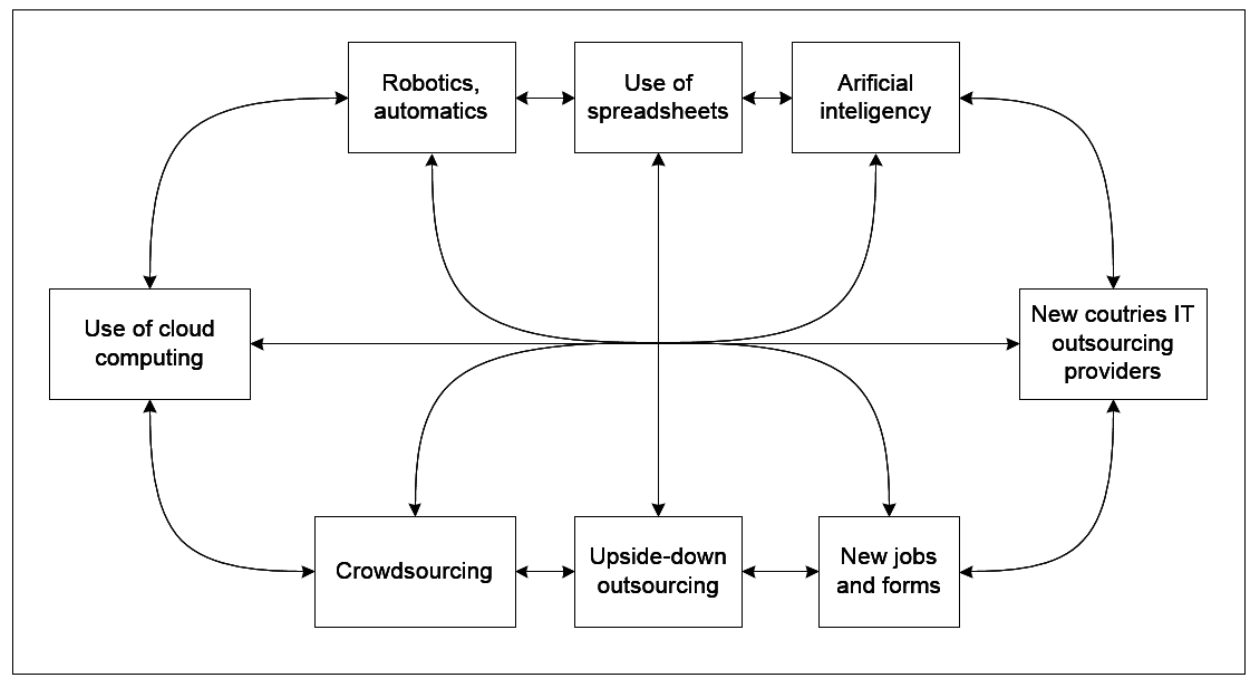

Figure 3. Graph of interdependence the news and the trends of OIT development

Source: own elaboration. 
NEWS IN

THE IT

OUTSOURCING

Jolanta Słoniec
Talking about trends another author names the following trends (Wallingford, 2016): using scrum, agile and lean methods, automation of processes, employment of innovative, talented people, new coutries and cities as IT oursourcing providers.

Summing topic presented in the article, the ITO market should be observed, we should continue to study the industry from both managerial and IT sites, because, according to forecasts of theoreticians and practitioners of the industry, this area will continue to grow dynamically. The value of the IT market and OIT are increasing and the growing trend will probably be maintained in the future, and this should imply a beneficial change in all aspects of the ITO industry.

\section{References}

Albin, M. (2016), "Polska mogłaby być światowym centrum outsourcingu IT, ale brakuje nam specjalistów”, avaliable at: www.benchmark.pl/aktualnosci/outsourcing-it-wpolsce-branza-rosnie-brakuje-pracownikow.html (accessed 15 December 2016).

Auksztol, J. (2008), Outsourcing informatyczny $w$ teorii i praktyce zarzadzania, Wydawnictwo Uniwersytetu Gdańskiego, Gdańsk.

Balentine, C. (2016), “Outsourcing Trends", Software magazine, avaliable at: www. softwaremag.com/outsourcing-trends (assessed 27 March 2017).

Baranowska-Skimina, A. (2015), "Outsourcing IT okiem dużych firm”, eGospodarka.pl, available at: www.egospodarka.pl/122817, Outsourcing-IT-okiem-duzych-firm,1,39,1. html (accessed 15 December 2016).

Bhushan Dhiraj, A. (2014), “Top 26 Outsourcing Destinations for Information Technology (IT) Companies: List of Countries", Ceoworld Magazine, avaliable at: ceoworld. biz/2014/09/15/top-26-outsourcing - destinations-for-information-technology-com panies-list-countries (assessed 27 March 2017).

Caldwell, B. (1996), “The New Outsourcing Partnership”, Information Week, No. 585, pp. $50-64$.

Cushman \& Wakefield, (2015), "Ranking najlepszych lokalizacji outsourcingowych świata", Outsourcing portal, avaliable at: www.outsourcingportal.eu/pl/rankingnajlepszych-lokalizacji-outsourcingowych-swiata, (accessed 27 March 2017).

Dzik, G. (2016), "Rynek pracy i IT przeobrażaj outsorcing”, Harvard Business Review, No. 164, available at: www.hbrp.pl/a/rynek-pracy-i-it-przeobrazaja-outsourcing/ IqLOlbzl (accessed 15 December 2016).

Grover, V., Cheon, M. J., Teng, T. C. (1996), “The Effect of Service Quality and Partnership on the Outsourcing of Information Systems Functions", Journal of Management Information Systems, Vol. 12 No. 4, pp. 89-116. DOI: http://dx.doi.org/10.1080/074 21222.1996.11518102

Grudzewski, W., Hejduk, I. (2004), Zarzq̨dzanie wiedza w przedsiębiorstwach, Difin, Warszawa.

Heeks, R., Krishna, S., Nicholson, B., Sahay, S. (2001), "Synching or Sinking: Global Software Outsourcing Relationships", IEEE Software, Vol. 18 No 2, pp. 54-60. DOI: http://dx.doi.org/10.1109/52.914744

Karasowski, M., Skalski, P. (2013), “Skuteczna infolinia kluczem do sukcesu firmy”, avail- 
able at: www.outsourcingportal.eu/pl/skuteczna-infolinia-kluczem-do-sukcesu-firmy (accessed 15 December 2016).

Kern, T., Willcocks, L. P. (2000), "Exploring Information Technology Outsourcing Relationship: Theory and Practice", Journal of Strategic Information Systems, Vol. 9 No. 4, pp. 321-350. DOI: http://dx.doi.org/10.1016/S0963-8687(00)00048-2

Kiviatkovski, M., Nowecka, M. (2016), "W cenie jest dostęp klientów do szybkiej informacji”, Harvard Business Review, No. 164, pp. 12-19.

Kluk, J. A. (2014), Model identyfikacji wymagań w outsourcingowych projektach informatycznych, Wydawnictwo Uniwersytetu Gdańskiego, Gdańsk.

Kłos, M. (2009), Outsourcing w polskich przedsiębiorstwach, Wydawnictwa Fachowe CeDeWu.pl, Warszawa.

Kopczyński, T. (2010), Outsourcing w zarzq̨zaniu przedsiębiorstwami, Polskie Wydawnictwo Ekonomiczne, Warszawa.

Lacity, M., Willcocks, L. (1998), "An Empirical Investigation of Information Technology Sourcing Practices: Lessons from Experience”, MIS Quarterly, Vol. 22 No. 3, pp. 363-408. DOI: http://dx.doi.org/10.2307/249670

Maciołek, C. (2016), "Rewolucja technologiczna tworzy wiele zawodów", Harvard Business Review, No. 164, pp. 10-16.

Marchand, N., Jacobsen, H. A. (2001), "An Economic Model to Study Dependencies between Independent Software Vendors and Application Service Providers", Electronic Commerce Research, Vol. 1 No. 3, pp. 315-334.

McLellan, K., Marcolin, B., Beamish, P. (1995), "Financial and Strategic Motivations behind IS Outsourcing", Journal of Information Technology, Vol. 10 No. 4, pp. 299-321. DOI: http://dx.doi.org/10.1057/jit.1995.32

Niedźwiedzka, H. (2002), "Outsourcing nowoczesnym narzędziem e-gospodarki”, Acta Universitatis Lodziensis Folia Oeconomica, No. 157, pp. 191-198.

Nogalski, B., Wójcik-Karpacz, A. (2003), "Outsourcing funkcji personalnej jako element poprawy konkurencyjności małych i średnich przedsiębiorstw“, in: Czarnota, J. L., Moszkowicz, M. (Eds.), W poszukiwaniu strategicznych przewag konkurencyjnych, Częstochowa, pp. 370-377.

Nogalski, B. (2010), “Outsourcing”, in: Czerska, M., Szpitter, A. (Eds.), Koncepcje zarządzania, Wydawnictwo C.H. Beck, Warszawa, pp. 281-283.

Overby, S. (2015), "10 outsourcing trends to watch in 2016", CIO from IDG, 29.12.2015, avaliable at: www.cio.com/article/3018638/outsourcing/10-outsourcing-trends-towatch-in-2016.html (assessed 27 March 2017).

Palvia, P. C. (1995), "A Dialectic View of Information Systems Outsourcing: Pros and Cons", Information \& Management, Vol. 29 No. 5, pp. 265-275. DOI: http://dx.doi. org/10.1016/0378-7206(95)00030-9

Podhorecka, W. (2016), “Technologia zmienia outsourcing”, Harvard Business Review, No. 164 , pp. 2-6.

Radło, M. J. (2013), Offshoring i outsourcing. Implikacje dla gospodarki i przedsiębiorstw, Oficyna Wydawnicza Szkoła Główna Handlowa w Warszawie, Warszawa.

Rhiza, C. (2016), "IT Outsourcing Trends 2016", Develops digest, avaliable at: www. devopsdigest.com/it-outsourcing-trends-2016 (assessed 27 March 2016). 
NEWS IN

THE IT

OUTSOURCING

Jolanta Słoniec
Trocki, M. (2001), Outsourcing. Metoda restrukturyzacji działalności gospodarczej, Państwowe Wydawnictwo Ekonomiczne, Warszawa.

Vesolovskij, S., Doktór, W. (2015), "Polska i Ukraina budują imperium outsourcingu IT", Outsourcing \& more, No. 6(25), pp. 16-21.

Wallingford, J. (2016), “3 IT Outsourcing trends to watch in 2016-2017”, Gorilla Logic, avaliable at: gorillalogic.com/blog/3-it-outsourcing-trends-to-watch-in-2016-2017 (assessed 27 March 2017).

Waszczuk, P. (2016), "Polska drugą po Indiach preferowaną lokalizacją outsourcingu IT", avaliable at: itwiz.pk/polska-druga-po-indiach-preferowana-lokalizacja-outsourcingu (assessed 27 March 2017).

Wędzicha, M. (2016), "Specjalista IT potrzebny od zaraz”, Harvard Business Review, No. 164 , pp. 8-11.

Williams, K., Krizan, A. C., Logan, J., Merrier, P. (2011), Communicating in business, South-Western Cengage Learning, United States.

Wroński, L., Kalinowski, J., Maruszczak, M. (2015), “Zupełnie nowy świat outsourcingu usług IT”, avaliable at: assets.kpmg.com/content/dam/kpmg/pdf/2016/03/ Raport-KPMG-Zupelnie-nowy-swiat-outsourcingu-uslug-IT-podsumowanie.pdf (accessed 15 December 2016).

Zakrzewska, L. (Ed.) (2016), “Outsourcing 2015/2016 Jakość usług i partnerskie relacje”, avaliable at: grantthornton.pl/wp-content/uploads/2015/10/OUTSOURCING_HBR_ GT_2015.pdf (accessed 27 March 2017). 